\title{
Microbiological analyses of nasally guided catheters after less invasive surfactant administration - a pilot study
}

\author{
Christian A. Maiwald ${ }^{1,2^{*}+}$ (D) Julia Dick ${ }^{3+}$, Matthias Marschal ${ }^{3}$, Christian Gille ${ }^{1}$, Axel R. Franz ${ }^{1,2}$ and Christian F. Poets
}

\begin{abstract}
Background: Respiratory distress syndrome (RDS) is a frequent complication of premature birth. Treating RDS by continuous positive airway pressure and less invasive surfactant administration (LISA) may reduce bronchopulmonary dysplasia. Surfactant, however, can be inactivated by bacterial infection. Therefore, potential routes of microbe transmission into the airway are of interest. The aim of this study was to evaluate microbiological contamination of catheters used for LISA procedures and its association with postnatal age.

Methods: Catheter tips used for LISA procedures via the nasal route (LISA-n) in infants with RDS were placed into a sterile eSwab container directly after the procedure, cultured and examined for microbiological contamination.

Results: Interpretable results could be collected from 20 catheter tips. Four showed positive culture results (20\%) with microbes potentially associated with the development of early onset neonatal sepsis. Risk of positive microbe detection increased with postnatal age (<4 h: 10\%; 4-18 h: 20\%; > 18 h: 40\%).

Conclusions: In this pilot study, the risk of tracheal microbe transmission following the LISA-n procedure increased with postnatal age. Although the clinical relevance of this finding is unclear, earlier surfactant administration might reduce the risk of catheter contamination.
\end{abstract}

Trial registration number: Substudy of the registered Trial: feasibility study - Neofact: NCT04086095, www. ClinicalTrials.gov, September 11, 2019.

Keywords: LISA, MIST, Neonate, Respiratory distress syndrome, Surfactant administration

\section{Background}

Pulmonary morbidity is a key issue in the treatment of premature infants. In the first postnatal days, respiratory distress syndrome (RDS) is, next to early-onset infection, one of the most important and common diseases affecting the lung.

\footnotetext{
* Correspondence: Christian.Maiwald@med.uni-tuebingen.de

${ }^{+}$Christian A. Maiwald and Julia Dick contributed equally to this work.

'Department of Neonatology, University Children's Hospital Tübingen, Tübingen, Germany

${ }^{2}$ Center for Pediatric Clinical Studies (CPCS), University Children's Hospital Tübingen, Tübingen, Germany

Full list of author information is available at the end of the article
}

Recent evidence suggests that RDS is best treated by continuous positive airway pressure (CPAP) combined with less invasive surfactant administration (LISA, [1-3]). Most reports using this approach administered surfactant via a thin catheter (TCA, [3-6]); this was also favored in a recent update of the European Consensus Guidelines on the Management of Respiratory Distress Syndrome [4].

Although most LISA reports and recently developed LISA catheters, such as LisaCath [5] or Neofact (formerly QuickSF [6]) prefer the oral route for insertion, the use of a nasally guided, soft umbilical vein catheter (LISA-n) is quite common in Germany. This involves the theoretical risk of catheter contamination

(c) The Author(s). 2020 Open Access This article is licensed under a Creative Commons Attribution 4.0 International License, which permits use, sharing, adaptation, distribution and reproduction in any medium or format, as long as you give appropriate credit to the original author(s) and the source, provide a link to the Creative Commons licence, and indicate if changes were made. The images or other third party material in this article are included in the article's Creative Commons licence, unless indicated otherwise in a credit line to the material. If material is not included in the article's Creative Commons licence and your intended use is not permitted by statutory regulation or exceeds the permitted use, you will need to obtain permission directly from the copyright holder. To view a copy of this licence, visit http://creativecommons.org/licenses/by/4.0/ The Creative Commons Public Domain Dedication waiver (http://creativecommons.org/publicdomain/zero/1.0/) applies to the data made available in this article, unless otherwise stated in a credit line to the data. 
with bacteria residing in the upper respiratory tract. It is unclear, however, how common this occurs in practice. We thus set out to quantify this risk in infants with RDS treated via LISA-n.

Main objective of this study was to evaluate microbiological contamination of the catheters used in LISA-n procedures and its association with postnatal age.

\section{Methods}

\section{Ethical conditions}

The study protocol was approved by the Ethics committee of University Hospital Tübingen. Samples were cultured anonymously (only numbered by order of occurrence). Parents gave written consent to their baby's study participation.

\section{Collection of samples}

We planned to collect 20 catheter tips from infants with RDS (gestational age, $23+0 / 7-36+0 / 7$ weeks) and a clinical indication of surfactant administration following the LISA-n procedure. Catheters used were umbilical vein catheters with a diameter of 2.5 to 3.5 French. Following surfactant administration, catheters were removed and the tip $(\sim 1-3 \mathrm{~cm})$ was cut with sterile scissors and directly placed in a sterile eSwab container with $1 \mathrm{ml}$ liquid Amies solution (Copan Diagnostics, Murrieta, CA). After that, they were sent anonymously (only labelled with the study title and the next consecutive number) to the microbiology laboratory for culture; this happened immediately after the procedure if occurring on weekdays between 8 am and $8 \mathrm{pm}$, or following storage in a refrigerator at $4-8{ }^{\circ} \mathrm{C}$ till the next morning. Room temperature was allowed for no more than $2 \mathrm{~h}$; also, if storage exceeded $24 \mathrm{~h}$, the sample was discarded.

A consignment note to each sample collected the details of the infant's medical history (e.g. postnatal age at the time of the procedure, number of surfactant administrations, etc.) and remained on the ward. Anonymization of the consignment note took place after reaching $48 \mathrm{~h}$ of postnatal age.

\section{Microbiological procedures}

Specimens were thoroughly vortexed and $10 \mu \mathrm{l}$ of Amies medium diluted in $990 \mu \mathrm{l}$ sterile sodium chloride solution (0.9\%). $100 \mu \mathrm{l}$ of the undiluted sample and $100 \mu \mathrm{l}$ of the dilution were then cultured for $48 \mathrm{~h}$ at $36 \pm 1{ }^{\circ} \mathrm{C}$ on the following solid media: Columbia sheep blood agar (Oxoid, Thermo Fisher Diagnostics, Wesel, Germany) and Endo agar supplemented with $1 \%$ fuchsine (Oxoid) under aerobic conditions, plus brain heart infusion agar (Oxoid) with 5\% sheep blood and IsoVitaleX enrichment (BD, Sparks, MD) under anaerobic conditions. Agar dishes were checked for microbial growth after 24 and $48 \mathrm{~h}$.
In case of growth, colony forming units (CFU) were counted and microbes identified based on morphology, hemolysis, catalase and/or DNase production, as well as Staph Plus Latex Kit (DiaMondiaL, Sees, France).

\section{Statistical analysis}

All analyses were descriptive and results were grouped by postnatal age: $<4 \mathrm{~h}, 4-18 \mathrm{~h},>18 \mathrm{~h}$.

\section{Results}

25 catheter-tips were collected between September 2018 and June 2019. Infants included into the study had a mean gestational age of 28 weeks (range 24-33 weeks). Baseline characteristics of the included infants, timing of the surfactant administrations, collection of samples and microbiological findings are shown in Table 1.

LISA- $n$ was performed from 1 to a maximum of 3 times (overall mean: 1.5 times; 1.3 times in positive samples and 1.6 times in negative samples). Mean postnatal age at sample collection was $11.0 \mathrm{~h}$ (range: $0.1-34.4 \mathrm{~h}$ ); it was 9.4 h (range: 0.1-34.4) in those with negative, and $17.3 \mathrm{~h}$ (range: $0.7-34.0 \mathrm{~h}$ ) in those with positive microbiological culture results.

Five catheter tips had to be excluded because storage time had been $>24 \mathrm{~h}$ or they came from an infant already enrolled. Of the remaining 20 catheter tips, 4 showed a positive culture result $(20 \%$, see Table 1$)$.

The calculated risk of catheter contamination increased with postnatal age (see Fig. 1).

\section{Discussion}

We found a $20 \%$ risk of bacterial contamination for nasally introduced catheters, which increased with postnatal age. All bacterial species identified are known to be potentially associated with the development of early onset neonatal sepsis [7]. We do not know, however, whether our findings would have any effect on clinical outcome. Since differentiation of radiological signs of pneumonia and RDS is difficult and biochemical and clinical signs of sepsis might be affected by other reasons (e.g. prenatal infection that could have caused premature birth) a much higher sample size would be required to assign such findings to the surfactant administration procedure.

Results of this study are limited by the fact that it remains unclear whether the bacteria from positive catheter tips had already colonized the trachea [8] or whether colonization took place during catheter removal, which would then not involve a risk of transmission. This would have required an additional intratracheal smear before implementation of the LISAcatheter, which was regarded too invasive.

However, colonization of the catheter tip took place during its pathway through the upper 
Table 1 Baseline characteristics of included infants, timing of surfactant doses, collection of samples and microbiological findings

\begin{tabular}{|c|c|c|c|c|c|c|}
\hline \multirow[t]{2}{*}{ No. } & \multirow{2}{*}{$\begin{array}{l}\text { Gestational } \\
\text { age at birth } \\
\text { in weeks }\end{array}$} & \multirow{2}{*}{$\begin{array}{l}\text { Weight } \\
\text { at birth } \\
\text { in gram }\end{array}$} & \multicolumn{3}{|c|}{$\begin{array}{l}\text { Time of surfactant administration after birth in hours: minutes } \\
{ }^{*} \text { cultured sample; }{ }^{*} \text { e collected, but excluded; }{ }^{--} \text {missed }\end{array}$} & \multirow[t]{2}{*}{$\begin{array}{l}\text { Microbiological findings Bacterium (Colony Forming } \\
\text { Units (CFU)) }\end{array}$} \\
\hline & & & 1st dose & 2nd dose & 3rd dose & \\
\hline 1 & $24+5 / 7$ & 345 & $00: 13^{--}$ & 09:09* & - & viridans group streptococci (160 CFU) \\
\hline 2 & $33+2 / 7$ & 1730 & $34: 23 *$ & - & - & - \\
\hline 3 & $29+0 / 7$ & 1190 & $05: 30 *$ & - & - & - \\
\hline 4 & $29+6 / 7$ & 1600 & $00: 22^{--}$ & $17: 22 *$ & - & - \\
\hline 5 & $25+0 / 7$ & 660 & $02: 10 * e$ & $17: 50 *$ & - & - \\
\hline 6 & $27+2 / 7$ & 980 & $01: 02 *$ & - & - & - \\
\hline 7 & $31+4 / 7$ & 2145 & $00: 12 *$ & - & - & - \\
\hline 8 & $28+6 / 7$ & 1340 & $01: 49 *$ & - & - & - \\
\hline 9 & $31+2 / 7$ & 1490 & $00: 20^{--}$ & $02: 38$ * & $18: 53^{--}$ & - \\
\hline 10 & $33+1 / 7$ & 1990 & $25: 21 *$ & - & - & $\begin{array}{l}\text { viridans group streptococci ( } 160 \mathrm{CFU}) \\
\text { coagulase-negative staphylococci }(90 \mathrm{CFU})\end{array}$ \\
\hline 11 & $30+0 / 7$ & 980 & $33: 58 *$ & - & - & coagulase-negative staphylococci (30 CFU) \\
\hline 12 & $30+2 / 7$ & 1220 & $00: 08 *$ & - & - & - \\
\hline 13 & $26+6 / 7$ & 655 & $26: 21 *$ & - & - & - \\
\hline 14 & $25+4 / 7$ & 495 & $02: 24 *$ & $37: 09^{--}$ & - & - \\
\hline 15 & $25+2 / 7$ & 685 & $00: 43 *$ & - & - & Staphylococcus aureus (60 CFU) \\
\hline 16 & $29+5 / 7$ & 1380 & $02: 56 *$ & - & - & - \\
\hline 17 & $24+6 / 7$ & 880 & $01: 14 *$ & $16: 12 * \mathrm{e}$ & - & - \\
\hline 18 & $25+4 / 7$ & 555 & $01: 03^{--}$ & $14: 20$ * & - & - \\
\hline 19 & $27+1 / 7$ & 585 & $00: 27 *$ & - & - & - \\
\hline 20 & $30+0 / 7$ & 780 & $14: 21^{--}$ & $17: 55 * e$ & $21: 40 *$ & - \\
\hline
\end{tabular}

respiratory tract (including the trachea) and by this there is a potential risk of microbe transmission when a LISA procedure is performed via the nasal route, as is probably also true for any nasally introduced endotracheal tube. Additionally, the risk of positive microbial culture results increased with postnatal age. This was expected owing to the fact that higher postnatal age will be accompanied with a higher rate of bacterial colonization of the pharynx and gastrointestinal tract.

Surfactant administration occurring immediately after birth is known to achieve a better effect in reducing air leaks than later surfactant administration. It also decreases the risk of pneumothorax, pulmonary interstitial

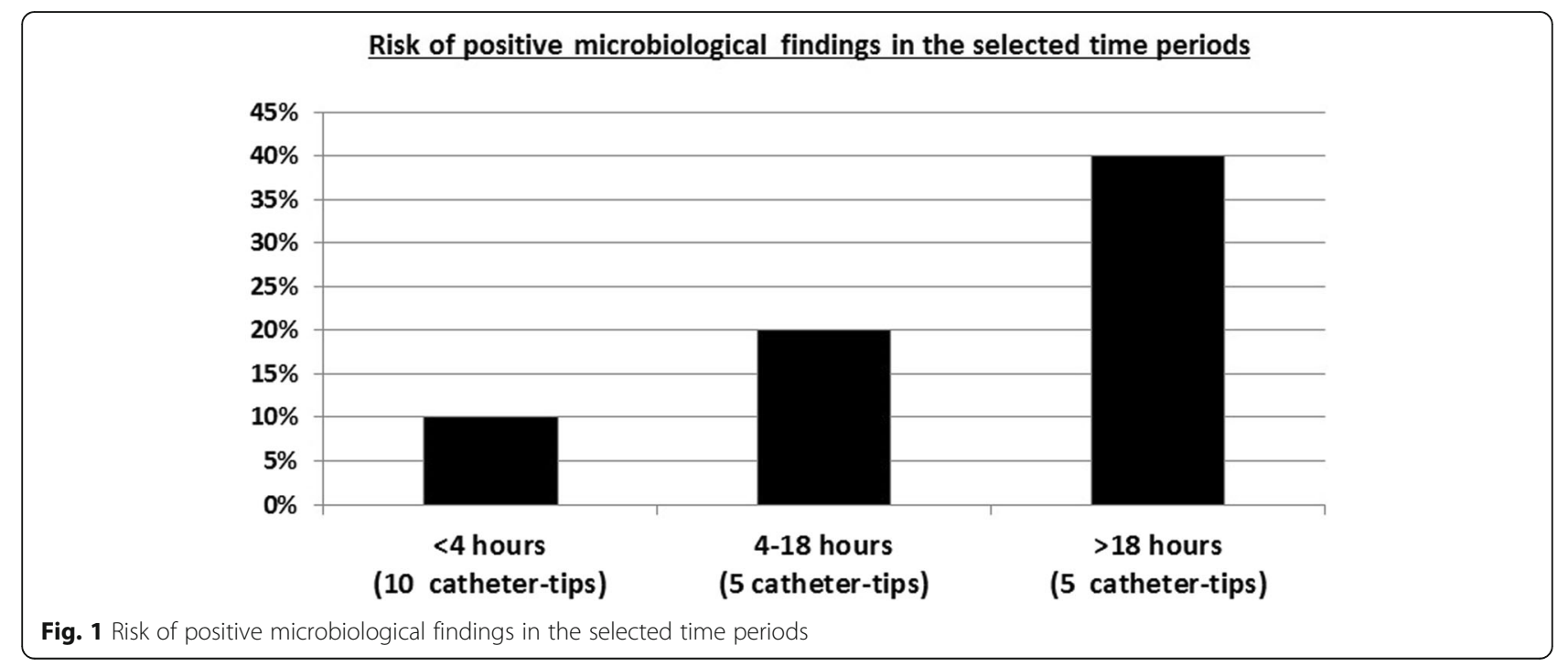


emphysema, neonatal mortality and chronic lung disease in comparison to later rescue surfactant [9]. Additionally, late surfactant administration may also increase the risk of patent ductus arteriosus [10]. An increasing risk of bacterial catheter contamination as shown here adds another argument why early identification of infants requiring exogenous surfactant is important.

\section{Conclusion}

It could be hypothesized that there is a potential risk of microbial transmission to the trachea of neonates in LISA-n procedures with higher postnatal age. However, it remains unclear if the findings of this study reflect the risk of transmission or colonization of the trachea. If there is a risk of microbe transmission, it is also unknown if orally guided catheters during LISA or other TCA procedures would minimize this risk. Earlier administration of surfactant after birth would reduce this risk, thus early identification of infants who require surfactant would be important.

Further studies will be needed to determine if these findings have any effect on clinical outcome.

\section{Abbreviations}

CPAP: Continuous positive airway pressure; LISA: Less invasive surfactant administration; LISA-n: Less invasive surfactant administration nasally guided catheter; RDS: Respiratory distress syndrome; TCA: Thin catheter administration

\section{Acknowledgements}

"Not applicable".

\section{Authors' contributions}

CAM and JD evolved the study protocol under the supervision of CG, ARF MM and CFP. CAM informed parents, obtained their consents for participation and collected the samples on the ward. JD cultured and diagnosed the samples in the laboratory. CAM and JD drafted the first version of the manuscript (shared first authorship). CG, ARF, MM and CFP revised the manuscript and made important contributions. All authors have read and approved the final manuscript.

\section{Funding}

This research project was enabled by a research funding from the Lyomark Pharma GmbH. Lyomark Pharma GmbH had no influence in the preparation of data or the manuscript.

Publication of this manuscript was supported by the Open Access Publishing Fund of the University of Tuebingen. They had no influence on the design of the study, on collection, analysis and interpretation of data and on writing this manuscript.

\section{Availability of data and materials}

The datasets used and/or analysed during the current study are available from the corresponding author on reasonable request.

\section{Ethics approval and consent to participate}

This trial was performed in accordance with the Declaration of Helsinki and the guidelines of Good Clinical Practice (GCP). Written informed consent was obtained by the parents or legal guardians before participation in the study. Ethical approval has been obtained by the Ethics Committee at the University Hospital Tuebingen, reference no. 111/2018BO2.

Consent for publication

"Not applicable".

\section{Competing interests}

All contributors declare that they do not have competing interests.

\section{Author details}

'Department of Neonatology, University Children's Hospital Tübingen, Tübingen, Germany. ${ }^{2}$ Center for Pediatric Clinical Studies (CPCS), University Children's Hospital Tübingen, Tübingen, Germany. ${ }^{3}$ Institute of Medical Microbiology and Hygiene, University Hospital Tübingen, Tübingen, Germany.

Received: 11 February 2020 Accepted: 14 May 2020

Published online: 19 May 2020

\section{References}

1. Lindner W, Vossbeck S, Hummler H, Pohlandt F. Delivery room management of extremely low birth weight infants: spontaneous breathing or intubation? Pediatrics. 1999;103(5 Pt 1):961-7.

2. Dani C, Bertini G, Pezzati M, Cecchi A, Caviglioli C, Rubaltelli FF. Early extubation and nasal continuous positive airway pressure after surfactant treatment for respiratory distress syndrome among preterm infants $<30$ weeks' gestation. Pediatrics. 2004;113(6):e560-3.

3. Kribs A, Pillekamp F, Hunseler C, Vierzig A, Roth B. Early administration of surfactant in spontaneous breathing with nCPAP: feasibility and outcome in extremely premature infants (postmenstrual age $</=27$ weeks). Paediatr Anaesth. 2007;17(4):364-9.

4. Sweet DG, Carnielli V, Greisen G, Hallman M, Ozek E, Te Pas A, et al. European consensus guidelines on the Management of Respiratory Distress Syndrome - 2019 update. Neonatology. 2019;115(4):432-50.

5. Fabbri L, Klebermass-Schrehof K, Aguar M, Harrison C, Gulczynska E, Santoro $D$, et al. Five-country manikin study found that neonatologists preferred using the LISAcath rather than the Angiocath for less invasive surfactant administration. Acta paediatrica (Oslo, Norway : 1992). 2018;107(5):780-3.

6. Maiwald CA, Neuberger P, Vochem M, Poets C. QuickSF: a new technique in surfactant administration. Neonatology. 2016;111(3):211-3.

7. Stoll BJ, Hansen NI, Sanchez PJ, Faix RG, Poindexter BB, Van Meurs KP, et al. Early onset neonatal sepsis: the burden of group B streptococcal and E. coli disease continues. Pediatrics. 2011;127(5):817-26.

8. Aly H, Badawy M, Tomerak RH, El-Kholy AA, Hamed AS. Tracheal colonization in preterm infants supported with nasal continuous positive airway pressure. Pediatrics international : official journal of the Japan Pediatric Society. 2012;54(3):356-60.

9. Bahadue FL, Soll R. Early versus delayed selective surfactant treatment for neonatal respiratory distress syndrome. Cochrane Database Syst Rev. 2012: 11:Cd001456

10. Canpolat FE, Kadioglu Simsek G, Webbe J, Buyuktiryaki M, Karacaglar NB, Elbayiyev S, et al. Late Administration of Surfactant may Increase the risk of patent Ductus Arteriosus. Front Pediatr. 2020;8:130.

\section{Publisher's Note}

Springer Nature remains neutral with regard to jurisdictional claims in published maps and institutional affiliations.
Ready to submit your research? Choose BMC and benefit from:
- fast, convenient online submission
- thorough peer review by experienced researchers in your field
- rapid publication on acceptance
- support for research data, including large and complex data types
- gold Open Access which fosters wider collaboration and increased citations
- maximum visibility for your research: over $100 \mathrm{M}$ website views per year
At BMC, research is always in progress.
Learn more biomedcentral.com/submissions 